\title{
Penerapan Model Discovery Learning Berbantuan Geogebra Untuk Meningkatkan Pemahaman Konsep Matematika Pada Persamaan Garis Lurus di SMPN 2 Peukan Pidie
}

\author{
Safriati \\ SMPN 2 Peukan Pidie, Aceh Indonesia \\ Email:ssafriayati@gmail.com
}

\begin{abstract}
Abstrak
Penelitian ini bertujuan untuk memperoleh perangkat pembelajaran berbasis discovery learning berbantuan Geogebra yang efektif dalam meningkattkan kemampuan pemahaman konsep matematika siswa SMP. Kriteria efektif bersandar pada teori intervensi pembelajaran yang meliputi adanya peningkatan capaian hasil belajar setelah intervensi, adanya respon positif siswa dan guru terhadap perangkat pembelajaran yang dikembangkan, keterlibatan (engagement) siswa yang tinggi dalam pembelajaran, serta diperoleh lebih dari $75 \%$ siswa mencapai skor 75 dari skala 100 dalam tes pemahaman konsep matematika. Peningkatan pemahaman konsep matematika diselidiki melalui indeks gain ternormalisasi. Peningkatan pemahaman konsep matematika dideskripsikan dengan bersandar pada statistik deskriptik. Penelitian ini menghasilkan perangkat pembelajaran yang memiliki karakteristik efektif dalam meningkatkan pemahaman konsep matematika siswa SMP sehingga siap untuk disebarluaskan. Disarankan agar guru lebih diberi kesempatan untuk mengimplementasikan perangkat pembelajaran yang dikembangkan sesuai dengan tujuan pembelajaran matematika sehingga dapat di harapkan siswa memperoleh kemampuan pemahaman konsep yang lebih tinggi lagi.
\end{abstract}

Kata Kunci: penelitian pengembangan; discovery learning; pemahaman konsep; Geogebra

\begin{abstract}
This study aims to obtain a Geogebra-assisted discovery learning-based learning tool that is effective in increasing the students' ability to understand mathematical concepts. Effective criteria rests on the theory of learning interventions which include an increase in learning outcomes after the intervention, a positive response from students and teachers to the learning tools developed, high student engagement in learning, and more than $75 \%$ of students achieving a score of 75 from a scale of 100 in a test of understanding mathematical concepts. Improved understanding of mathematical concepts is investigated through a normalized gain index. Improved understanding of mathematical concepts is described by relying on descriptive statistics. This research produces learning tools that have effective characteristics in improving junior high school students' understanding of mathematical concepts so that they are ready to be disseminated. It is recommended that teachers be given more opportunities to implement learning tools developed in accordance with the objectives of learning mathematics so that students can expect higher understanding of concepts.
\end{abstract}

Keywords: development research; discovery learning; concept understanding;

Geogebra 


\section{PENDAHULUAN}

\section{Latar Belakang}

Hasil observasi di lapangan dan pengalaman peneliti menunjukkan bahwa pemahaman peserta didik terhadap matematika masih kurang, khususnya materi persamaan garis lurus. Berdasarkan wawancara dengan guru matematika SMP Negeri 2 Peukan Pidie Kabupaten Pidie, guru menginformasikan bahwa penguasaan materi persamaan garis lurus yang diuji pada ulangan harian masih rendah. Sebagian besar peserta didik kesulitan dalam membedakan konsep persamaan garis lurus serta menyelesaikan soal atau masalah yang berkaitan dengan persamaan garis lurus. Hal ini dapat terjadi karena penerapan model pembelajaran di kelas yang sering monoton dan berpusat pada guru sehingga peserta didik tidak terlibat secara aktif dalam pembelajaran. Akibatnya, pemahaman konsep persamaan garis lurus tidak melekat lama dalam ingatan peserta didik serta pembelajaran menjadi kurang bermakna.

\section{Berdasarkan permasalahan}

tersebut, diperlukan suatu penerapan model pembelajaran yang dapat meningkatkan kemampuan pemahaman konsep matematika peserta didik. Model pembelajaran yang dapat merangsang peserta didik untuk bekerja dan menemukan sendiri konsepnya adalah pembelajaran dengan model discovery learning. Discovery learning atau pembelajaran penemuan merupakan proses pembelajaran yang menitikberatkan pada mental intelektual peserta didik dalam memecahkan berbagai persoalan yang dihadapi, sehingga menemukan suatu konsep atau generalisasi yang dapat diterapkan di lapangan (Solikin, 2017:29). Dengan menerapkan model pembelajaran discovery learning, peserta didik akan terlibat secara langsung dalam menemukan ide dan konsep matematika (Suryanti, 2015) sehingga peserta didik dapat menemukan konsep secara mandiri dan pembelajaran lebih bermakna.

\section{Rumusan Masalah}

Berdasarkan latar belakang di atas, maka fokus permasalahan yang dapat dirumuskan dalam penelitian ini adalah : 
1) Bagaimanakah penerapan model pembelajaran

Discovery

Learning berbantuan GeoGebra dapat meningkatkan pemahaman konsep matematika peserta didik pada materi persamaan garis lurus di kelas VIII SMPN 2 Peukan Pidie?

2) Bagaimanakah penerapan model pembelajaran Discovery Learning berbantuan GeoGebra pada materi persamaan garis lurus terhadap peningkatan aktivitas belajar peserta didik di kelas VIII SMPN 2 Peukan Pidie?

\section{Tujuan Penelitian}

Adapun tujuan penelitian yang ingin dicapai adalah sebagai berikut :

1) Untuk meningkatkan pemahaman konsep matematika peserta didik melalui penerapan model pembelajaran Discovery Learning berbantuan GeoGebra pada materi persamaan garis lurus di kelas VIII SMPN 2 Peukan Pidie.

2) Untuk meningkatkan aktivitas belajar peserta didik melalui penerapan model pembelajaran Discovery Learning berbantuan GeoGebra pada materi persamaan garis lurus di kelas VIII SMPN 2 Peukan Pidie.

\section{Manfaat Penelitian}

Hasil penelitian ini diharapkan dapat memberi konstribusi yang berarti sebagai berikut :

\section{Manfaat Teoritis}

Hasil penelitian ini diharapkan mampu memberikan gambaran tentang pembelajaran matematika yang nantinya dapat meningkatkan hasil belajar siswa.

\section{Manfaat Paraktis}

\section{Bagi Peserta Didik}

a. Peserta didik terlatih untuk mampu mengaitkan materi yang sudah dipelajari untuk menemukan konsep pengetahuan baru.

b. Peserta didik akan terlibat secara langsung dalam menemukan konsep secara mandiri sehingga pembelajaran lebih bermakna dan pengetahuan yang diperoleh akan melekat dalam jangka waktu yang lama.

\section{Bagi Guru}

a. Dapat memberikan informasi tentang kemampuan pemahaman konsep matematika peserta didik melalui penerapan model pembelajaran yang memposisikan peserta didik sebagai student 
centered (pembelajaran dipusatkan kepada peserta didik).

b. Sebagai bahan alternatif dan masukan dalam pembelajaran agar guru selalu memperhatikan perkembangan, kemampuan, dan kesulitan yang di alami oleh peserta didiknya sehingga tujuan pembelajaran dapat tercapai dengan baik.

\section{Bagi Sekolah}

Tindakan yang dilakukan pada penelitian ini diharapkan dapat dijadikan sebagai bahan masukan dan manfaat dalam rangka meningkatkan pemahaman konsep matematika peserta didik.

\section{Bagi Peneliti}

Memberikan pengalaman lapangan tentang kemampuan pemahaman konsep matematika peserta didik dengan menerapkan model pembelajaran discovery learning berbantuan Geogebra

\section{KAJIAN PUSTAKA}

Untuk mengukur tingkat pemahaman konsep peserta didik diperlukan suatu indikator pemahaman konsep. Adapun indikator dari pemahaman konsep matematika peserta didik yang peneliti gunakan dalan penelitian ini adalah Indikator pemahaman konsep menurut Permendikbud No.59 tahun 2014 yaitu

a. Menyatakan ulang konsep yang telah dipelajari;

b. Mengklasifikasikan objek-objek berdasarkan dipenuhi tidaknya persyaratan yang membentuk konsep tersebut;

c. Memberikan contoh atau contoh kontra (bukan contoh) dari konsep yang dipelajari;

d. Menyajikan konsep dalam berbagai macam bentuk representasi matematis (tabel, grafik, diagram, gambar, sketsa, model matematika, atau cara lainnya);

e. Mengembangkan syarat perlu dan syarat cukup dari suatu konsep;

f. Menggunakan, memanfaatkan dan memilihproseduar atau operasi tertentu;

g. Mengaplikasikan konsep atau algoritma ke pemecahan masalah.

\section{Model Pembelajaran Discovery}

\section{Learning}

\section{Pengertian Model Pembelajaran}

\section{Discovery Learning}

Discovery learning merupakan suatu rangkaian kegiatan pembelajaran 
yang melibatkan secara maksimal seluruh kemampuan peserta didik untuk mencari dan menyelidiki secara sistematis, kritis, dan logis, sehingga mereka dapat menemukan sendiri pengetahuan, sikap dan keterampilan sebagai wujud adanya perubahan perilaku (dalam Novriandita, 2014:13).

Menurut Azwan (2017:22) secara garis besar prosedur Discovery Learning adalah sebagai berikut:

\section{a. Simulation}

Guru mulai bertanya dengan mengajukan persoalan atau menyuruh anak didik membaca atau mendengarkan uraian yang memuat permasalahan

\section{b. Problem statement}

Peserta didik diberi kesempatan untuk mengidentifikasi berbagai permasalahan. Sebagian besar memilihnya yang dipandang paling menarik dan fleksibel untuk dipecahkan. Permasalahan yang dipilih itu selanjutnya harus dirumuskan dalam bentuk pertanyaan (statement) sebagai jawaban sementara atas pertanyaan yang diajukan.

\section{c. Data collection}

Untuk menjawab pertanyaan atau membuktikan benar tidaknya hipotesis ini, anak didik diberi kesempatan untuk mengumpulkan berbagai informasi yang relevan, membaca literatur, mengamati objek, wawancara dengan narasumber, melakukan uji coba sendiri dan sebagainya.

\section{d. Data processing}

Semua informasi hasil bacaan, wawancara, observasi dan sebagainya semua diolah, diacak, diklasifikasikan, ditabulasikan, bahkan bila perlu dihitung dengan cara tertentu serta ditafsirkan pada tingkat kepercayaan tertentu.

\section{e. Verification}

Berdasarkan hasil pengolahan dan tafsiran atau informasi yang ada, pertanyaan atau hipotesis yang telah dirumuskan terdahulu kemudian dicek, apakah terjawab atau tidak, apakah terbukti atau tidak.

\section{f. Generalization}

Tahap selanjutnya berdasarkan hasil verifikasi tadi, anak didik belajar menarik kesimpulan atau generalisasi tertentu

Penerapan model Discovery Learning pada materi persamaan garis lurus dapat dilihat pada tabel 1 berikut ini.

Tabel 1. Penerapan model Discovery Learning pada materi Persamaan Garis Lurus

\begin{tabular}{|c|c|}
\hline $\begin{array}{l}\text { Langkah- } \\
\text { langkah }\end{array}$ & Kegiatan Guru \\
\hline $\begin{array}{l}\text { Fase-1 } \\
\text { Stimulation }\end{array}$ & $\begin{array}{llr}\text { - } & \text { Guru } & \text { mengecek } \\
& \text { kemampuan } & \text { prasyarat }\end{array}$ \\
\hline
\end{tabular}




\begin{tabular}{|c|c|}
\hline $\begin{array}{l}\text { (pemberian } \\
\text { rangsangan) }\end{array}$ & $\begin{array}{lr}\text { peserta didik untuk } \\
\text { menggali pemahaman } \\
\text { konsep mengenai } \\
\text { pengetahuan } r \text { yang } \\
\text { dimiliki, yaitu dengan } \\
\text { memberikan } \\
\text { pertanyaan-pertanyaan } \\
\text { mengenai r operasi } \\
\text { bilangan bulat, operasi } \\
\text { aljabar, dan sistem } \\
\text { koordinatryntuk } \\
\text { dikaitkan dengan } \\
\text { persamaan garis lurus. } \\
\text { Peserta didik diberikan } \\
\text { masalah kontekstual } \\
\text { untuk diamati } \\
\text { disertakan gambar } \\
\text { menarik yang tidak } \\
\text { asing dengan kehidupan } \\
\text { peserta didik terkait } \\
\text { dengan grafik } \\
\text { persamaan garis lurus. } \\
\text { Guru memotivasi } \\
\text { peserta didik dengan } \\
\text { menyampaikan manfaat } \\
\text { mempelajari persamaan } \\
\text { garis lurus. }\end{array}$ \\
\hline
\end{tabular}

Hipotesis Tindakan

Hipoesis tindakan dari penelitian ini adalah :

1) Pemahaman konsep matematika peserta didikdapat meningkat melalui penerapan model pembelajaran Discovery

Learning berbantuan GeoGebra pada materi persamaan garis lurus di kelas VIII SMPN 2 Peukan Pidie.

2) Aktivitas belajar peserta didik dapat meningkat melalui penerapan model pembelajaran Discovery Learning berbantuan GeoGebra pada materi persamaan garis lurus di kelas

VIII SMPN 2 Peukan Pidie.

\section{METODE PENELITIAN}

\section{Pendekatan dan Jenis Penelitian}

Pendekatan yang digunakan dalam penelitian ini adalah pendekatan kualitatif. Jenis penelitian pada penelitian ini adalah penelitian tindakan kelas. Penelitian kualitatif adalah penelitian yang bermaksud untuk memahami fenomena yan dialami oleh subjek penelitian misalnya: perilaku, persepsi, motivasi, tindakan dan sebagainya secara holistik dan dengan cara deskripsi dalam bentuk kata-kata dan bahasa, pada suatu konteks khusus yang alamiah dan dengan memanfaatka berbagai metode alamiah. Sugiono (2008:13) mengatakan bahwa pada umumnya alasan meggunakan metode kualitatif karena permasalahan belum jelas holistik, kompleks, dinamis, dan penuh makna. Dalam penelitian kualitatif masalah yang akan dipecahkan melalui penelitian harus jelas, spesifik dan dianggap tidak berubah. Rencana tindakan yang telah disusun dipraktikkan oleh peneliti saat melakukan pembelajaran dikelas dengan diamati dan dinilai oleh para 
observer saat pembelajaran

berlangsung.

\section{Setting Penelitian}

\section{Lokasi Penelitian}

Penelitian ini berlokasi di SMPN 2 Peukan Pidie, jalan Garot, Kampong Pukat, Kabupaten Pidie

\section{Waktu Penelitian}

Penelitian ini dilaksanakan selama 3 bulan yaitu pada bulan September sampai dengan bulan November 2020 semester Ganjil Tahun Pelajaran 2020/2021. Dilakukan pada waktu tersebut karena materi Persamaan Garis Lurus merupakan materi yang diajarkan pada semester tersebut.

\section{Subjek Penelitian}

Subjek pada penelitian ini adalah peserta didik kelas VIII-A SMP Negeri 2 Peukan Pidie tahun ajaran 2020/2021 yang terdiri dari 30 peserta didik. Adapun yang menjadi objek penelitian adalah keseluruhan proses dan hasil pembelajaran dari implementasi model pembelajaran discovery learning berbantuan GeoGebra yang dapat meningkatkan pemhaman konsep peserta didik pada materi Persamaan Garis Lurus.

\section{Teknik Pengumpulan Data}

Data yang diperlukan dalam penelitian ini dikumpulkan melalui:

Tes pemahaman konsep, tes yang diberikan berupa ulangan harian (UH) ini dilakukan sebanyak dua kali yaitu setelah proses pembelajaran berakhir dalam masing-masing siklus.Lembar Aktivitas Guru, digunakan untuk memperoleh data tentang aktivitas guru. Berisi komponen-komponen yang perlu diamati selama pembelajaran.

Lembar Aktivitas Siswa, yang digunakan adalah lembar penilaian aktivitas siswa sebagai alat untuk mengukur perkembangan aktifitas siswa terhadap proses pembelajaran pada setiap pertemuan.

\section{Teknik Analisis Data}

Analisis data dilakukan secara terencana setelah penelitian tindakan kelas dilaksanakan. Hal ini dilakukan untuk mendapatkan hasil yang akurat agar dapat mengambil tindak lanjut dari pertemuan berikutnya. Data yang diperoleh dari penelitian ini berupa data hasil tes dan pengamatan aktifitas peserta didik selama penerapan model discovery learning berbantuan GeoGebra pada setiap siklus. Data yang telah diperoleh akan dianalisis 
secara deskriptif kualitatif. Adapun pengolahannya adalah sebagai berikut :

\section{Analisis Tes Pemahaman Konsep}

Untuk mengetahui ketuntasan hasil belajar peserta didik, digunakan rumus persentase menurut Mukhlis (2015:74) adalah:

$$
\begin{gathered}
P=\frac{\text { Jumlah siswa yang tuntas }}{\text { Jumlah siswa keseluruhan }} \\
\times 100 \%
\end{gathered}
$$

Peserta didik dianggap tuntas jika mencapai nilai Kriteria Ketuntasan Minimal yang diterapkan di sekolah yaitu 75. Sedangkan untuk ketuntasan belajar secara klasikal tercapai bila $\geq$ 85\% peserta didik di kelas tersebut telah mencapai ketuntasan belajar.

Setelah menganalisis ketuntasan hasil belajar peserta didik, peneliti juga menganalisis rata-rata persentase pencapaian setiap indikator pemahaman konsep matematika yang diuji dengan rubrik indikator pemahaman konsep matematika pada lampiran 3 sehingga dapat dirumuskan sebagai berikut :

Persentase Indikator = $\frac{\text { Jumlah skor seluruh siswa }}{\text { Jumlah skor maksimal seluruh siswa }} \times 100 \%$
Selanjutnyua, kemampuan pemahaman konsep matematika tersebut dapat dikualifikasikan sebagai berikut :

Tabel 2 Kualifikasi Pemahaman Konsep

\begin{tabular}{|lll|}
\hline & $\begin{array}{l}\text { Rata-Rata } \\
\text { Indikator }\end{array}$ & Kualifikasi \\
\hline 2 & $81-100$ & $\begin{array}{l}\text { Sangat } \\
\text { Tinggi }\end{array}$ \\
3 & $61-80,99$ & Tinggi \\
4 & $41-60,99$ & Cukup \\
5 & $21-40,99$ & Rendah \\
6 & $0-20,99$ & Sangat \\
& & Rendah \\
\hline
\end{tabular}

(Adaptasi dari Arikunto, 2013)

Data aktivitas siswa selama kegiatan pembelajaran berlangsung dianalisis dengan menggunakan rumus persentase sebagai berikut:

$$
\text { Pas }=\frac{F}{N} \times 100 \%
$$

Dimana:

Pas = Persentase Aktivitas Siswa

$\mathrm{F} \quad=$ Jumlah siswa yang memiliki kesamaan jawaban tertentu

$\mathrm{N} \quad=$ Jumlah siswa keseluruhan

Kriteria klasifikasi persentase aktivitas siswa selama pembelajaran adalah sebagai berikut berikut (Sudjono: 2010). 
Tabel 3 Kualifikasi Persentase Aktivitas

Siswa

\begin{tabular}{|l|l|l|}
\hline Skor & Persentase & Kategori \\
\hline 5 & $\mathbf{8 1 - 1 0 0}$ & Sangat Aktif \\
\hline 4 & $61-80$ & Aktif \\
\hline 3 & $41-60$ & Cukup Aktif \\
\hline 2 & $21-40$ & $\begin{array}{l}\text { Kurang } \\
\text { Aktif }\end{array}$ \\
\hline 1 & $\mathbf{0 - 2 0}$ & Tidak Aktif \\
\hline
\end{tabular}

\section{Prosedur Penelitian}

Bentuk penelitian ini adalah Penelitian

Tindakan Kelas (PTK) kolaboratif.

\section{Siklus I}

\section{Perencanaan}

Pada tahap ini, hal-hal yang perlu dipersiapkan oleh peneliti adalah menyusun silabus, membuat Rencana Pelaksanaan Pembelajaran (RPP), Lembar Kerja Peserta Didik (LKPD), butir soal beserta rubrik penilaian sebagai tes hasil belajar untuk menilai kemampuan pemahaman konsep peserta didik, lembar pengamatan aktivitas guru dan peserta didik selama proses kegiatan belajar mengajar.

\section{Pelaksanaan}

Pelaksanaan tindakan merupakan implementasi dari perencanaan. Pelaksanaan tindakan akan dilakukan sesuai dengan langkah-langkah model pembelajaran discovery learning.

\section{Pengamatan}

Pengamatan dilakukan setiap kali pertemuan tentang aktivitas guru dan peserta didik pada penerapan model pembelajaran discovery learning. Pengamatan dimulai dari kegiatan awal, kegiatan inti sampai kegiatan akhir. Kemudian hasilnya dideskripsikan secara rinci pada lembar pengamatan. Setelah itu akan dilakukan analisis terhadap lembar pengamatan.

\section{Refleksi}

Refleksi merupakan suatu upaya untuk mengkaji aktivitas dan hasil belajar yang dicapai atau yang belum dicapai. Refleksi dilakukan dengan cara berdiskusi dengan pengamat mengenai pelaksanaan tindakan yang telah dilakukan. Dari hasil refleksi, guru dapat mencatat berbagai kekurangan yang perlu diperbaiki, sehingga dapat dijadikan dasar dalam penyusunan rencana yang ditetapkan pada siklus berikutnya.

\section{Siklus II}

SIklus II merupakan tindak lanjut dari hasil evaluasi atau berdasarkan dari refleksi siklus I. Langkah kegiatan pada siklus II sama seperti pada siklus I, yaitu terdiri dari empat langkah. 
Secaraumum uraian siklus II adalah sebagai berikut:

Perencanaan: Identifikasi masalah dan penetapan alternative pemecahan masalah serta pengembangan program tindakan II.

Tindakan: Pelaksanaan program tindakan II

Observasi: Pengumpulan data tindakan II

Refleksi: Evaluasi tindakan II

Jika hasil yang diperoleh dalam siklus II telah mencapai indicator kinerja, maka peneliti dapat menganalisis data dan menyusun laporan. Jika hasil yang diperoleh dalam siklus II belum mencapai indikator keberhasilan, maka peneliti dapat melanjutkan dengan siklus berikutnya dengan tahapan yang sama.

\section{HASIL PENELITIAN DAN PEMBAHASAN}

Peneliti melaksanakan penelitian tindakan kelas di SMP Negeri 2 Peukan Pidie dalam dua siklus, yaitu siklus I yang terdiri dari satu kali pertemuan dan siklus II selama satu kali pertemuan dan tes untuk siklus 1 dan siklus II diadakan diakhir pertemuan. Penelitian dilaksanakan selama 2 minggu, dimulai dari hari Senin tanggal 19 Oktober 2020 sampai dengan hari Senin tanggal 04 November 2020. Subjek dalam penelitian ini adalah peserta didik kelas VIII-A SMP Negeri 2 Peukan Pidie yang berjumlah 30 orang.

Pengamatan terhadap sikap
peserta didik selama kegiatan
pembelajaran berlangsung diawali
dengan menggunakan lembar observasi
sikap peserta didik. Lembar observasi yang telah disiapkan, diisi oleh pengamat pada saat proses pembelajaran berlangsung dengan model pembelajaran discovery learning. Bedasarkan hasilnya, terdapat peningkatan dari pertemuan pertama dan kedua. Pada indikator Tanggung Jawab yang ditunjukkan peserta didik, rata-rata indikator pada pertemuan pertama yaitu 3.1 dengan persentase $77.5 \%$ Pada indikator rasa ingin tahu yang mengukur keaktifan peserta didik 2.83 dengan persentase $70.83 \%$ dengan persentase $74,17 \%$

Tabel 4. Rekapitulasi Hasil Tes Formatif Peserta Didik pada Siklus I

\begin{tabular}{|cll|}
\hline NO & \multicolumn{1}{c|}{ Uraian } & $\begin{array}{c}\text { Hasil pada } \\
\text { Siklus I }\end{array}$ \\
\hline 1 & $\begin{array}{l}\text { Jumlah skor yang } \\
\text { tercapai }\end{array}$ & 2225 \\
2 & $\begin{array}{l}\text { Jumlah siswa yang } \\
\text { tuntas }\end{array}$ & 16 Orang \\
3 & $\begin{array}{l}\text { Persentase ketuntasan } \\
\text { yang tercapai }\end{array}$ & $53,33 \%$ \\
\hline
\end{tabular}


$4 \begin{aligned} & \text { Nilai rata-rata tes } \\ & \text { formatif }\end{aligned}$

Berdasarkan tabel di atas dapat kita simpulkan bahwa dengan pembelajaran model discovery learning di peroleh nilai rata-rata hasil belajar peserta didik adalah 74.17 dengan presentase ketuntasan yang tercapai adalah 53.33 $\%$ atau 16 peserta didik yang tuntas dari 30 orang pada pembelajaran siklus I. Hasil ini menunjukkan bahwa pada siklus pertama baik secara klasikal maupun KKM nilai peserta didik belum tercapai, karena siswa yang memperoleh nilai $\geq 75$ hanya 16 orang atau jika dipresentasekan hanya 53.33 \% saja yang mencapai nilai ketuntasan. Jika dibandingkan dengan ketuntasan kalsikal yang sudah ditetapkan yaitu $85 \%$, maka hasil ini masih jauh berada di bawah kriteria.

Data hasil belajar peserta didik diukur berdasarkan rubrik indikator pemahaman konsep, data pemahaman konsep matematika peserta didik ditinjau melalui beberapa indikator pemahaman konsep yang telah dipilih, berikut data kemampuan pemahaman konsep matematika peserta didik selama siklus 1 per indikator.

\section{Pelaksanaan Siklus II}

pengamatan terhadap sikap peserta didik mengalami peningkatan dari siklus I terhadap dua indikator yang di amati, Pada indikator Tanggung Jawab yang ditunjukkan peserta didik, rata-rata indikator pada siklus pertama yaitu 3,1 dengan persentase $77.5 \%$ mengalami peningkatan pada siklus kedua, kenaikan rata-rata menjadi 3,86 dengan persentase $96,67 \%$. Pada indikator rasa ingin tahu yang mengukur keaktifan peserta didik juga mengalami peningkatan, rata-rata indikator rasa ingin tahu pada pertemuan pertama 2,83 dengan persentase $70,83 \%$ juga mengalami peningkatan pada pertemuan kedua, kenaikan rata-rata menjadi 3.66 dengan persentase $91,67 \%$.

Tabel 5. Rekapitulasi Hasil Tes Formatif Peserta Didik pada Siklus II

\begin{tabular}{|cll|}
\hline NO & \multicolumn{1}{c|}{ Uraian } & \multicolumn{1}{c|}{$\begin{array}{c}\text { Hasil pada } \\
\text { Siklus I }\end{array}$} \\
\hline 1 & $\begin{array}{l}\text { Jumlah skor yang } \\
\text { tercapai }\end{array}$ & 2396 \\
2 & $\begin{array}{l}\text { Jumlah siswa yang } \\
\text { tuntas }\end{array}$ & 26 Orang \\
3 & $\begin{array}{l}\text { Persentase ketuntasan } \\
\text { yang tercapai }\end{array}$ & $86,67 \%$ \\
4 & $\begin{array}{l}\text { Nilai rata-rata tes } \\
\text { formatif }\end{array}$ & 79,88 \\
\hline
\end{tabular}

Data kemampuan pemahaman konsep matematika peserta didik diperoleh dari hasil belajar peserta didik melalui pemberian soal tes di akhir siklus. Data pemahaman konsep matematika peserta didik ditinjau 
melalui beberapa indikator pemahaman konsep yang telah dipilih, berikut data kemampuan pemahaman konsep matematika peserta didik selama siklus II per indikator.

\section{Pembahasan}

Berdasarkan hasil penelitian setelah peneliti melakukan upaya menerapkan model pembelajaran discovery learningternyata hasilnya cukup memuaskan. Peneliti memfokuskan penelitian pada ketuntasan hasil belajar peserta didik yang diukur dengan indikator pemahaman konsep matematika, selain itu peneliti juga memfokuskan pada sikap yang ditunjukkan peserta didik selama proses belajar mengajar berlangsung.

Hasil belajar peserta didik yang diukur dengan indikator pemahaman konsep matematika mengalami peningkatan dari siklus I ke siklus II. Pada siklus I, nilai rata-rata hasil belajar peserta didik adalah 74.18 dengan persentase ketuntasan hasil belajar yang tercapai adalah 53.33\% atau 16 peserta didik yang tuntas dari 30 orang. Hasil belajar pada siklus I menunjukkan bahwa secara klasikal ketuntasan hasil belajar peserta didik belum berhasil karena ketuntasan hanya mencapai 53.33\% dari indikator yang diharapkan mencapai 85\%. Pada siklus II, nilai rata-rata hasil belajar peserta didik adalah 79,88 dengan persentase ketuntasan hasil belajar yang tercapai adalah $86,67 \%$ atau 26 peserta didik yang tuntas dari 30 orang. Hasil belajar pada siklus II menunjukkan bahwa secara klasikal ketuntasan hasil belajar peserta didik sudah berhasil karena ketuntasan mencapai $86,67 \%$ dari indikator yang diharapkan mencapai $85 \%$.

Berdasarkan gambar di atas, maka hasil belajar peserta didik mengalami peningkatan dari siklus I ke siklus II melalui penerapan model pembelajaran discovery learning yang dilihat dari peningkatan rata-rata hasil belajar serta persentase ketuntasan hasil belajar.

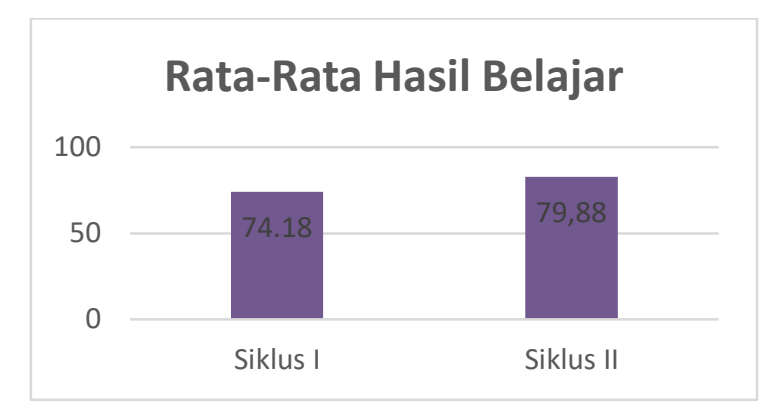

Gambar 1.Grafik Peningkatan RataRata Hasil Belajar Peserta Didik 


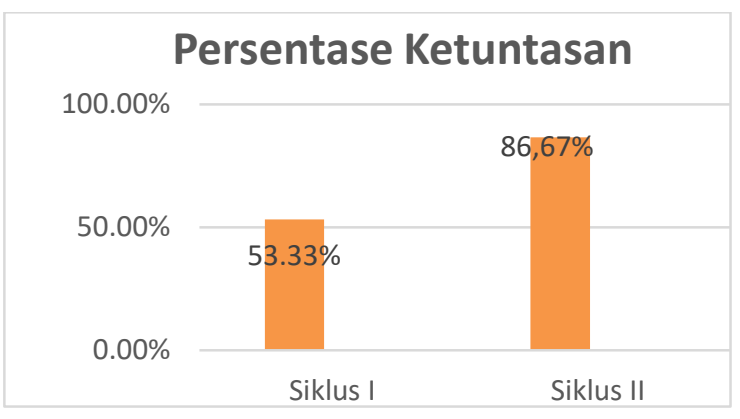

Gambar 2. GrafikPersentase Ketuntasan Hasil Belajar

Kemampuan pemahaman konsep yang terdiri dari empat indikator yang diteliti juga mengalami peningkatan dari siklus I ke siklus II. Pada siklus I terdapat satu indikator yang berada pada kualifikasi sangat tinggi, dua indikator pada kualifikasi tinggi dan satu indikator pada kualifikasi cukup sedangkan pada siklus II terdapat dua indikator pada kualifikasi sangat tinggi dan dua indikator pada kualifikasi tinggi. Pada indikator mengklasifikasikan objek-objek berdasarkan dipenuhi tidaknya persyaratan yang membentuk konsep tersebut serta memodelkannya mengalami peningkatan sebesar $12.08 \%$ dari $84.17 \%$ dengan kualifikasi sangat tinggi pada siklus I ke 96.25\% dengan kualifikasi juga sangat tinggi pada siklus II. Pada indikator menyatakan ulang sebuah konsep mengalami peningkatan sebesar $10.21 \%$ dari $73.33 \%$ dengan kualifikasi tinggi pada siklus I ke $83.54 \%$ dengan kualifikasi sangat tinggi pada siklus II. Pada indikator menggunakan, memanfaatkan dan memilih prosedur atau operasi tertentu mengalami peningkatan sebesar $2.5 \%$ dari $72.5 \%$ dengan kualifikasi tinggi pada siklus I ke 75\% dengan kualifikasi tinggi pada siklus II. Pada indikator menyajikan konsep dalam berbagai bentuk representasi matematis juga mengalami peningkatan $11.67 \%$ dari $55.83 \%$ dengan kualifikasi cukup pada siklus I ke $67.5 \%$ dengan kualifikasi tinggi pada siklus II.

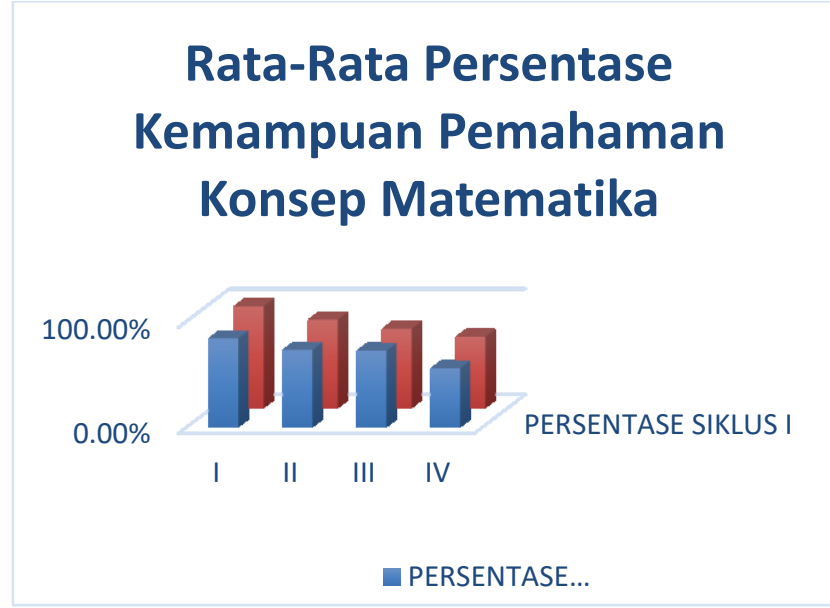

Gambar 3. Rata-Rata Persentase Kemampuan Pemahaman Konsep Matematika dari Empat Indikator yang Diukur

peneliti juga meninjau sikap yang ditunjukkan oleh peserta didik selama proses belajar mengajar berlangsung, terdapat peningkatan sikap yang ditunjukkan oleh peserta didik dari siklus I ke siklus II. Indikator sikap 
Tanggung Jawab mengalami peningkatan dari $77,5 \%$ pada siklus I dengan kualifikasi baik menjadi 96\% pada siklus II dengan kualifikasi juga sangat baik. Indikator sikap rasa ingin tahu juga mengalami peningkatan dari $70,83 \%$ pada siklus I dengan kualifikasi baik menjadi $91 \%$ pada siklus II dengan kualifikasi sangat baik.

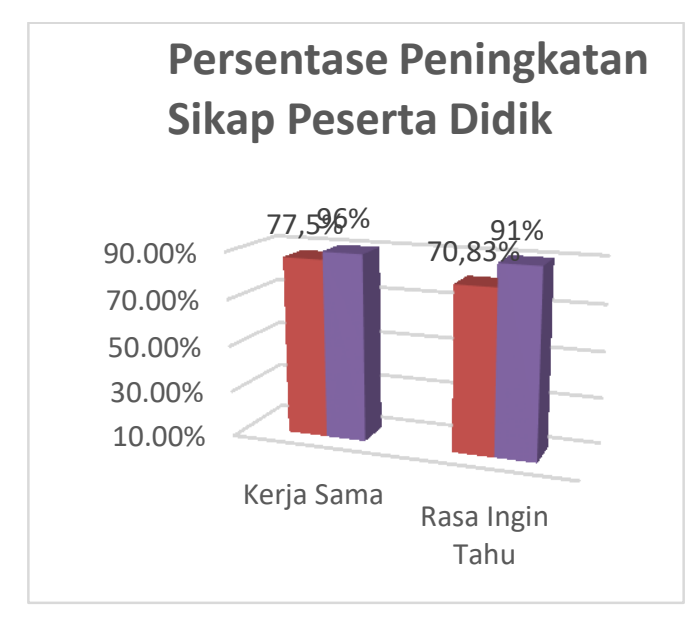

Gambar 4. Persentase Peningkatan Sikap Peserta Didik Selama Pembejaran dengan Penerapan Discovery Learning

Berdasarkan hasil deskripsi di atas, keseluruhan indikator keberhasilan penelitian ini tercapai sehingga dapat disimpulkan bahwa penerapan model discovery learning pada materi persamaan garis lurus dapat meningkatkan pemahaman konsep matematika peserta didik serta sikap atau aktivitas belajar peserta didik di kelas VIII-A SMP Negeri 2 Peukan Pidie

\section{PENUTUP}

\section{Simpulan}

Berdasarkan hasil penelitian yang telah dilakukan dapat diambil beberapa kesimpulan sebagai berikut:

Penerapan model discovery learning berbantuan Geogebra dapat meningkatkan ketuntasan hasil belajar peserta didik kelas VIII-A SMP Negeri 2 Peukan Pidie. Pernyataan ini didukung oleh fakta di lapangan dimana nilai rata-rata peserta didik mengalami peningkatan dari 74.18 dengan persenntase ketuntasan 53.33\% menjadi 79,88 dengan persentase ketuntasan $86.67 \%$.

Penerapan model discovery learning berbantuan Geogebra dapat meningkatkan kemampuan pemahaman konsep matematika peserta didik kelas VIII-A SMP Negeri 2 Peukan Pidie. Hal ini ditunjukkan dengan peningkatan indikator yang diuji pada tes tertulis dimana kemampuan mengklasifikasikan objek menurut sifat tertentu dan menyatakan ulang sebuah konsep juga berada pada kualifikasi sangat tinggi sedangkan kemampuan operasi matematika dan menyajikan masalah dalam berbagai representasi matematis berada pada kualifikasi tinggi. 
Penerapan model pembelajaran discovery learning berbantuan Geogebra dapat meningkatkan sikap belajar peserta didik. Hal ini ditunjukkan dengan peningkatan pada sikap tanggung jawab dan rasa ingin tahu dimana kedua indikator sikap tersebut berada pada kualifikasi sangat baik.

\section{Saran}

Berdasarkan hasil penelitian yang telah dilakukan, maka disarankan kepada beberapa pihak sebagi berikut:

\section{Bagi Guru}

Guru diharapkan dapat menerapkan model pembelajaran discovery learning dalam meningkatkan pemahaman konsep matematika peserta didik serta memperbaiki factor-faktor yang menjadi kendala dalam pembelajaran agar dapat mencapai tujuan yang diharapkan dengan rancangan Lembar Kegiatan Peserta Didik yang terbimbing.

\section{Bagi Peserta didik}

Model pembelajaran discovery learning dapat dimanfaatkan peserta didik agar pembelajaran lebih bermakna dan melekat lebih lama.

Model pembelajaran discovery learning dapat dimanfaatkan pula untuk meningkatkan partisipasi aktif peserta didik selama pembelajaran di kelas.

Pemahaman konsep dasar seperti operasi matematika harus selalu dilatih agar peserta didik mampu menggunakan operasi tertentu untuk menyelesaikan masalah.

\section{Bagi Sekolah}

Sekolah hendaknya memberikan dukungan kepada guru dalam bentuk bimbingan dan pembinaan tentang metode pembelajaran inovatif dan efektif agar keberhasilan pembelajaran di dalam kelas tercapai.

\section{UCAPAN TERIMAKASIH}

Ucapan terimakasih yang sebesarbesarnya disampaikan kepada Kepala SMPN 2 Peukan Pidie, yang telah memberi tempat dan waktu untuk pelaksa- naan penelitian ini. Dan Guru - guru teman sejawat yang sudah mendukung pelaksanaan kegiatan penelitian ini. Sehingga berjalan lancar.

\section{DAFTAR PUSTAKA}

Arikunto, dkk. 2013.Penelitian Tindakan Kelas, Bumi Aksara, Jakarta. 
Bisri, Ahmad. 2015. Strategi Pembelajaran Berbasis Standar Proses Pendidikan. Jakarta: Kanisius.

Dahar,R.W. 2016. Teori-Teori Belajar dan Pembelajaran. Jakarta:Erlangga.

Dewi,I.A.,Japa,I.G.N.,dkk. 2016. Pengaruh Masalah Realistik terhadap Pemahaman Konsep Matematika bagi Siswa Kelas V Gugus VII Kecamatan Buleleng. Mimbar PGSD, 4(1),23-30.

Ghazali, Hasnida,N.,dkk. 2016. Students Procedural and Conceptual Understanding of Mathematics. Australian Journal of Basic and Applied Science, 5(7).684-691.

Susanto. 2015.

Manajemen

Pengembangan Kurikulum.

Bandung: Remaja Rosdakarya.

Lamibao,L.

S.,

Luna,C.A.,\&Namoco,R.A. 2016. The Influence of Mathematical Communication on Student's Mathematics Perform. American Journal of Education Research, 4(5),376-382.

Murizal,A., dkk. 2017. Pemahaman Konsep Matematis dan Model Pembelajaran Quantum Teaching.
Jurnal Pendidikan Matematika, I(1), 19-23.

Solikin, dkk. 2017. Konsep dan Makna Pembelajaran untuk Membantu Memecahkan Problematika belajar dan Mengajar. Bandung : Alfabeta

Sardiman. 2015. Interaksi dan motivasi belajar mengajar. Jakarta: Raja grafindo Persada.

Suherman,dkk. 2018. Strategi Pembelajaran Matematika Kontemporer. Bandung: JICAUPI.

Suryanti, S. (2015). Peningkatan kepercayaan diri dan kemampuan pemecahan masalah mahasiswa pada mata kuliah matematika diskrit melalui discovery learning. DIDAKTIKA: Jurnal Pemikiran Pendidikan, 22(1), 64-73. https://doi.org/doi:10.1234/didakti ka.v22i1.148

Walle,V,D. 2018. Sekolah Dasar dan Menengah Matematika Pengembangan Pengajaran. Jakarta : Kencana Prenada Media Group 
